\title{
VON WILLEBRAND DISEASE
}

\section{Putu Reyhan Irza Dhaneswara}

Fakultas Kedokteran, Universitas Mataram, Indonesia.

Email: reyhanirza123@gmail.com

\begin{abstract}
Abstak
Von Willebrand disease merupakan kelainan perdarahan herediter yang disebabkan oleh defisiensi faktor von Willebrand. Prevalensi von Willebrand disease diperkirakan berkisar kurang lebih 1\% dari populasi umum sampai 125 kasus yang terbukti secara klinis per sejuta populasi. Penyebab utama penyakit ini adalah penurunan kadar atau fungsi faktor von Willebrand yang abnormal akibat suatu mutasi titik atau delesi besar sehingga menyebabkan gangguan struktur dan sintesis faktor von Willebrand. Gejala paling umum meliputi perdarahan gusi, hematuri, epistaksis, perdarahan saluran kemih, darah dalam fesese, mudah memar, menoragi. Terdapat beberapa tipe penyakit von Willebrand (VWD), yaitu tipe 1, tipe 2A, dan tipe 2B yang diturunkan secara autosomal dominant, dan tipe $2 \mathrm{~N}$, tipe 3 diturunkan secara autosomal resesif. Penatalaksanaan kasus VWD dilakukan secara umum adalah dengan pemberian obat, transfusi plasma, dan menghindari keadaan yang dapat menyebabkan rudapaksa atau perdarahan.
\end{abstract}

Kata Kunci: Penyakit von Willebrand, faktor von Willebrand, faktor VIII

\section{Abstract}

Von Willebrand disease is a hereditary bleeding disorder caused by a deficiency of von Willebrand factor. The prevalence of von Willebrand disease is estimated to range from approximately $1 \%$ of the general population to 125 clinically proven cases per million population. The main cause of this disease is a decrease in the level or function of abnormal von Willebrand factor due to a point mutation or large deletion that causes disruption of the structure and synthesis of von Willebrand factor. The most common symptoms include bleeding gums, hematuria, epistaxis, urinary tract bleeding, blood in the stool, easy bruising, and menorrhagia. There are several types of von Willebrand disease (VWF), namely type 1, type $2 A$, and type $2 B$ which are inherited in an autosomal dominant manner, and type $2 N$, type 3 is inherited in an autosomal recessive manner. Management of VWD cases is generally carried out by administering drugs, plasma transfusions, and avoiding conditions that can cause involuntary injury or bleeding.

Keyword: von Willebrand disease, von Willebrand factor, VIII factor

Diserahkan: 12-01-2022Ｄiterima: 25-01-2022Ｄiterbitkan: 20-02-2022 


\section{Pendahuluan}

Darah adalah komponen esensial makhluk hidup yang berada dalam ruang vaskuler, karena perannya sebagai media komunikasi antar sel ke berbagai bagian tubuh dengan dunia luar karena fungsinya membawa oksigen dari paru-paru ke jaringan dan karbondioksida dari jaringan ke paru-paru untuk dikeluarkan, membawa zat nutrien dari saluran cerna ke jaringan kemudian mengantarkan sisa metabolisme melalui organ sekresi seperti ginjal, menghantarkan hormon dan materi-materi pembekuan darah (Hasanan, 2018).

Mekanisme pembekuan darah berlangsung secara bertahap sedemikian rupa sehingga salah satu faktor koagulasi diubah menjadi aktif diakhiri dengan pembentukan fibrin (bekuan). Faktor koagulasi atau faktor pembekuan darah adalah protein yang terdapat dalam darah (plasma) yang berfungsi dalam proses koagulasi. Proses pembekuan darah bertujuan untuk mengatasi vascular injury sehingga tidak terjadi pendarahan berlebihan, tetapi proses pembekuan darah ini dilokalisir pada daerah injury (Putri, 2021).

Terdapat banyak faktor pembekuan darah, salah satunya adalah faktor Von Willebrand, apabila terdapat gangguan pada faktor Von Willebrand, maka akan menyebabkan penyakit Von Willebrand. Penyakit Von willebrand adalah kelainan perdarahan herediter yang disebabkan oleh defisiensi faktor von Willebrand. Defisiensi faktor von willebrand akan menyebabkan sulitnya trombosit melekat pada dinding pembuluh darah dan antara sesamanya, yang diperlukan untuk pembekuan darah yang normal (Murni \& Mayenti, 2019).

Penyakit VWD merupakan gangguan koagulasi herediter yang paling sering terjadi. Prevalensi penyakit Von Willebrand diperkirakan berkisar kurang lebih $1 \%$ dari populasi umum sampai 125 kasus yang terbukti secara klinis per sejuta populasi. Di indonesia sendiri kasus ini belum banyak ditemukan, tujuan dari penulisan artikel ini adalah untuk memberikan informasi kepada masyarakat mengenai penyakit Von Willebrand serta memberi manfaat bagi tenaga kesehatan untuk tahu mengenai penyakit Von Willebrand (Chunaeni et al., 2019).

\section{Metode Penelitian}

Penulisan artikel ini menggunakan berbagai jenis sumber yang berasal dari jurnal ilmiah. Pencarian sumber dilakukan di portal online publikasi jurnal seperti Pusat Nasional untuk Informasi Bioteknologi / NCBI (ncbi.nlm.nih.gov) dan Google Scholar (scholar.google.com). Kata kunci yang digunakan adalah "Von Willebrand Disease", "Faktor Von Willebrand", dan "Faktor VIII" (Triandini et al., 2019).

\section{Hasil dan Pembahasan}

\section{A. Definisi}

Penyakit von Willebrand atau biasa yang disingkat VWD (von willebrand disease) merupakan kelainan perdarahan herediter yang disebabkan oleh defisiensi 
faktor von Willebrand (selanjutnya disingkat fVW). vWF akan membantu trombosit melekat pada dinding pembuluh darah dan antara sesamanya, yang diperlukan untuk pembekuan darah yang normal (Bakta, 2006).

Faktor von Willebrand dikode oleh gen pada kromosom 12. fVW merupakan suatu glikoprotein multimer heterogen adesif yang terikat pada berbagai ligands dalam plasma dan matriks subendothelium. Memiliki 2 peran utama, yaitu:

1. Berperan pada mekanisme hemostasis primer tingkat sel yaitu memudahkan adhesi trombosit pada kondisi stress berat dengan menghubungkan reseptor membran trombosit ke subendotel pembuluh darah

2. Sebagai protein pembawa atau pelindung untuk faktor VIII (FVIII), suatu protein koagulasi darah yang penting, dan melindungi FVIII terhadap degradasi proteolitik oleh protein C aktif (Hoffrand et al., 2005).

\section{B. Etiologi}

Penyebab utama penyakit ini adalah penurunan kadar atau fungsi fVW yang abnormal akibat suatu mutasi titik atau delesi besar sehingga menyebabkan gangguan struktur dan sintesis fVW (Hasan et al., 2016). Gangguan ini akan menyebabkan 2 hal yang utama, yaitu gangguan adhesi trombosit, dan menurunnya aktivitas FVIIIC dalam plasma.

Terdapat beberapa klasifikasi atau varian dari VWD, yaitu:

- $\quad$ Tipe 1: defisiensi kuantitatif parsial fVW (kadar abnormal)

- $\quad$ Tipe 2: defisiensi kualitatif fVW (bentuk abnormal)

$\mathrm{x}$. Tipe $2 \mathrm{~A}$ penurunan fungsi yang tergantung trombosit disertai tidak adanya multimer fVW berat molekul tinggi

x. Tipe 2B varian dengan afinitas meningkat untuk glikoprotein Ib (GPIb) trombosit

$\mathrm{x}$. Tipe $2 \mathrm{M}$ seperti tipe $2 \mathrm{~A}$ tetapi masih terdapat multimer fVW

$\mathrm{x}$. Tipe $2 \mathrm{~N}$ varian dengan afinitas menurun terhadap FVIII

- $\quad$ Tipe 3 defisiensi fVW total (lengkap)

C. Epidemiologi

Penyakit VWD merupakan gangguan koagulasi herediter yang paling sering terjadi. Prevalensi VWD diperkirakan berkisar kurang lebih $1 \%$ dari populasi umum sampai 125 kasus yang terbukti secara klinis per sejuta populasi. Penyakit ini dapat timbul di berbagai kelompok etnik. Dari penelitian, sekitar $81 \%$ pVW merupakan tipe 1 yang ringan sedangkan sisanya adalah tipe 2 dengan berbagai bentuk kelainan dan yang terbanyak ialah tipe $2 \mathrm{~A}, 2 \mathrm{~B}, 2 \mathrm{~N}$. Tipe 3 merupakan tipe paling berat dan sangat jarang terjadi. Tipe 1, 2A, 2 B diturunkan secara autosomal dominant, sedangkan tipe $2 \mathrm{~N}$ dan tipe 3 merupakan autosomal recessive. Namun, di Indonesia kasus ini belum banyak dilaporkan (Wantania, 2016).

\section{Patogenesis}

Pada von willebrand disease (VWD) terdapat penurunan aktivitas faktor VIIIVwF dan faktor WIII $_{\mathrm{AHG}}$. Faktor von willebrand disintesis di dalam sel-sel endotel dan megakariosit serta disimpan di dalam organel penyimpanan. FVW mempermudah 
adhesi trombosit pada komponen-komponen di dalam subendotel vaskular di bawah keadaan aliran yang tinggi dan bertekanan, serta faktor ini merupakan karier intravaskular untuk FVIII di tempat perdarahan aktif saat adhesi trombosit (Proboningsih, 2020).

Mikrofibril subendotelial mengikat vWF yang selanjutnya mengikat trombosit ke reseptor glikoprotein Iib/Iia (GPIIb/IIIa) trombosit yang berikatan lebih lanjut dengan vWF. Reseptir GPIIb/IIa juga mengikat fibrinogen sehingga terjadi agregasi trombosit-trombosit. Trombosit yang terkativasi ini selanjutnya meningkatkan koagulasi, karena memiliki tempat pengikatan fosfolipid yang terpajan yang terlibat dalam aktivasi faktor $\mathrm{X}$ dan aktivasi protrombin menjadi trombin pada kaskade koagulasi (Mehta \& Hoffbrand, 2008). Pada penyakit von willebrand, trombosit tidak melekat pada kolagen karena adanya defisiensi atau kelainan dari faktor von willebrand.

\section{E. Manifestasi Klinis}

Gambaran klinis VWD adalah bervariasi tergantung keparahan dan subtipe penyakit. Gejala paling umum meliputi perdarahan gusi, hematuri, epistaksis, perdarahan saluran kemih, darah dalam fesese, mudah memar, menoragi. Pada pasien dengan tipe yang berat seperti tipe 3 yang tidak adanya fVW dapat terjadi perdarahan seperti hemofilia seperti hemartrosis, hematoma dan perdarahan berat lain setelah trauma dengan tendensi perdarahan pada pembuluh darah kecil yang tidak dijumpai pada hemofilia, dapat juga terjadi manifestasi seperti perdarahan jaringan dalam tubuh (Bakta et al., n.d.).

\section{F. Diagnosis}

Diagnosis VWD memerlukan kecurigaan terhadap gambaran klinis tingkat tinggi dan kecakapan pemanfaatan laboraturium. Bila pasien dalam kondisi kritis sulit menetapkan diagnosis yang tepat. Bila VWD dianggap merupakan faktor penunjang pada perdarahan pasien, lebih dahulu harus diobati secara empiris dan penelusuran laboratoris yang rumit ditunda sampai pasien secara klinis stabil dan tidak mendapat obat dan produk darah dalam seminggu (Price \& Wilson, 2005).

Hasil pemeriksaan laboratorium biasanya beragam, beberapa yang sering ditemukan adalah:

- $\quad$ APTT memanjang, PT normal

- Kadar faktor VIII dan fVW berkurang

- Waktu perdarahan memanjang

- Fungsi trombosit terganggu, agregasi terganggu yang diperiksa dengan penentuan kadar kofaktor ristosetin (biasanya berkurang)

- Dapat terjadi trombositopenia ringan

Beragamnya tes laboratorium dikaitkan pada sifat-sifat kelainan yang heterogen pada VWD.

a. Penyakit tipe 1

Walaupun tipe ini merupakan yang terbanyak dijumpai, namun masih memberikan masalah pada diagnosisnya. Beratnya gambaran klinis tipe ini sangat bervariasi dan tergantung dengan penurunan kadar FVIII dan fVW. 
Beberapa hal yang perlu diperhatikan dalam menegakkan diagnosis tipe ini yaitu adanya bukti riwayat keluarga, adanya riwayat perdarahan abnormal dan pemeriksaan yang menunjukkan defisiensi fVW. Biasanya pada pasien yang menunjukkan gejala menunjukkan penuruan aktifitas fVW dibawal 50\% nilai normal. Pasien dengna golongan darah $\mathrm{O}$ pada umumnya menunjukkan nilai fVW normal rendah dan tidak boleh langung didiagnosis sebagai fVW tipe ringan. Biasanya terjadi pemanjangan APTT.

b. Penyakit tipe 2

- Tipe $2 \mathrm{~A}$

Tipe ini ditandai oleh fVW yang kekurangan multimer protein berukuran besar dan sedang akibat ketidakmampuan membentuk multimer berat molekul tinggi atau terbentuknya multimer yang mudah dipecah secara proteolitik. Sub tipe ini mencakup sekitar 15\% dari kasus FVW dan dalam keluarga berifat autosomal dominant. Pemeriksaan kadar fVW:RCo relatif rendah terhadap kadar fVW:Ag. Kadar FVIII dapat rendah atau normal sedangkan agregasi trombosi oleh ristocetin menurun.

- $\quad$ Tipe 2B

Tipe ini merupakan bentuk mutan dalam (gian of function) dari VWD. Karena, pada tipe ini bentuk mutan fVW berikatan dengan afinitas tinggi pada reseptor GPIb dari trombosit, sehingga menyebabkan penurunan selektif fVW bentuk multimetrik dari plasma. Pengikatan mutan fVW pada trombosit, mengakibatkan terbentuknya agregasi trombosit sehingga terjadi trombositopenia. Oleh karena itu tipe ini harus dipikirkan sebagai diagnosis banding pada trombositopenia bawaan. Pasien dengan tipe 2B ini juga mempunyai kadar fVW:Rco yang relatif rendah terhadap fVW;Ag, tetapi terdapat peningkatan agregasi trombosit yang diinduksi resositin dosis rendah. Tipe ini diturunkan dengan autosomal dominant.

- $\quad$ Tipe $2 \mathrm{M}$

Tipe yang jarang ditemukan dan ditandai oleh penurunan secara tidak proporsional kadar fVW; Rco relatif terhadap fVW;Ag. Seperti pada tipe 2A dan 2B, tetapi multimer dalam plasma dalam trombosit normal serta agregasi trombosit oleh ristocetin menurun.

- $\quad$ Tipe $2 \mathrm{~N}$

Tipe ini diturunkan secara resesif seperti pada tipe 3, dan pada pemeriksaan laboratorium hanya ditemukan penurunan FVIII. Tipe $2 \mathrm{~N}$ ini disebut juga sebagai bentuk autosomal hemofilia A. Kecendurungan perdarahan biasanya ringan dengan FVIII rendah.

c. Penyakit tipe 3

Tipe ini diturunkan secara autosomal resesif, ditandai dengan tidak ditemukannya fVW;Ag dalam sirkulasi dan derajat VIIIC sangatlah rendah (3 $10 \%$ normal). Pasien seperti ini menunjukkan perdarahan berat dengan 
hemartrosis dan hematoma muskulus serupa pasien hemofilia A dan B. Bleeding time sangat memanjang.

\section{G. Penatalaksanaan}

Pengelolaan Segera.

Fungsi trombosit yang abnormal sering yang pertama tampak sebagai komplikasi penyakit akut atau pembedahan. Beberapa faktor pemberat dapat menentukan beratnya tendensi perdarahan. Pada keadaan demikiam diagnosis yang tepat dapat ditunda, namun tindakan harus disesuaikan dengan sebanyak mungkin faktor pendorong yang potensial (Rofinda, 2012). Termasuk;

- Menghentikan obat yang menghambat fungsi trombosit

- Secara emperis memberikan fVW

- Transfusi trombosit yang normal, tergantung beratnya perdarahan

Kelainan fungsi trombosit yang didapat maupun kongenital dapat segera diatasi dengan mengontrol perdarahan klinis yang berat.

Pengelolaan jangka panjang.

Pasien dengan kelainan kongenital harus dinasehati untuk menghindari obat ataupun aktifitas yang memperberat kelainan fungsi dan menyebabkan perdarahan. Seperti;

- Aspirin dan analgesik nonsteroid. Pasien VWD dan trombasteni menunjukkan pemanjangan BT dengan pemberian aspirin dan menunjukkan resiko lebih besar terhadap perdarahan klinis

- Pasien harus benar-benar diajari tentang kelainan yang dideritanya

- Membawa serta identifikasi atau memakai gelang peringatan.

Desmopressin (DDAVP)

Desmopressin merupakan suatu analog sintesis dari hormon antidiuretik vasopressin. DDAVP biasanya digunakan untuk pasien dengan VWD tipe I dan 2A, dan juga dapat digunakan untuk mengontrol perdarahan ringan, secara profilaktik digunakan sebelum prosedur pembedahan. Pemberian DDAVP dapat dilakukan secara subkutan, IV dan intranasal dan akan menaikkan kadar fVW dan FVIII dalam plasma sebanyak 28 kali dengan jalan melepaskan fVW dari penyimpanannya dalam sel endotel (badan Weibel-Palade) (Fithrah et al., 2019).

Pemberian IV dilakukan dengan infus dengan dosis $0,3 \mathrm{mg} / \mathrm{kgBB}$ (maksimum $20 \mathrm{mg}$ ) dalam 10-50 ml saline selama kurang lebih 20 menit dan puncak respons dapat dilihat dalam waktu 30 menit. Sedangkan pemberian intranasal (dosis lebih tinggi) akan tampak dalam waktu 90 menit. Efek samping yang dapat ialah muka merah, sakit kepala, peningkatan sedikit tekanan darah dan denyut jantung.

Pemberian DDAVP dikontraindikasikan pada VWD tipe 2B. Pada keadaan ini, stimulasi pengeluaran fVW dapat menyebabkan peningkatan agregasi trombosit dan memperburuk keadaan trombositopeni pasien. Penanganan yang tepat pada pasien ini adlaah dengan penambahan fVW dan transfusi trombosit.

Selain banyak digunakan untuk pasien VWD tipe 1 dan tipe 2A, biasanya tipe $2 \mathrm{M}$ juga mempunyai respon yang baik dengan pemberian DDAVP. Namun, pemberian 
pada pasien tipe $2 \mathrm{~N}$ dan tipe 3 biasanya tidak memerikan respon. Utamanya pada tipe 3 , sebab pada pasien ini sudah tidak ada persedian fVW di endotel. Jadi pemberian fVW maupun faktor VIII harus disiapkan pada pasien tipe 2N dan tipe 3 (Sudoyo, 2009).

Faktor von Willebrand.

Penggantian fVW dapat dilakukan dengan transfusi plasma segar atau konsentrat plasma mengandung kompleks fVW-FVIII

Kriopresipitat adalah konsentrat yang mudah didapat dan efektif. Efeknya dapat segera memperpendek BT namun dapat berlangsng relatif singkat. Kadar kriopresipitat cepat rusak dalam 6-12 jam setelah diberikan melalui infus, pada waktu yang bersamaan akan terjadi kenaikan kadar FVIIIC selama 24 jam beriikutnya. Kenaikan kadar FVIII tampaknya untuk memberikan efek protektif.

Apabila kriopesipitat tidak didapatkan, salah satu bentuk consentrat facor VIII/fVW dapat diberikan. Namun, konsentrat tersebut harus mengandung multimer fVW besar agar efektif. Dosis fVIII 50 U/kg tiap 12 jambiasanya akan cukup. Keuntungan sediaan-sediaan ini adlaah kurang memberikan resiko transmisi virus.

Pasien VWD tipe 3 mempunyai resiko timbulnya antibodi terhadap fVW setelah transfusi sediaan plasma tersebut. Sekali ini terjadi, pasien mempuunyai resiko reaksi anafilaktoid dan infus fVW berikutnya jadi kurang efektif. Pemberian antihistamin dan steroid dapat mengaburkan reaksi anafilktoid.

\section{Kesimpulan}

Penyakit von Willebrand merupakan suatu penyakit atau kelainan perdarahan herediter yang disebabkan oleh defisiensi faktor von Willebrand (fVW). Faktor von Willebrand merupakan suatu glikoprotein yang memiliki 2 peran utama, yaitu memudahkan adhesi trombosit dengan menghubungkan reseptor membran trombosit ke subendotel pembuluh darah dan berperan sebagai protein pembawa atau pelindung untuk faktor VIII (FVIII) dan melindungi FVIII terhadap degradasi proteolitik oleh protein $\mathrm{C}$ aktif. Defisiensi fVW dapat terjadi karena gangguan struktur dan sintesis dari faktor tersebut, sehingga menyebabkan gangguan pada fungsinya.

Terdapat beberapa tipe penyakit von Willebrand (VWD), yaitu tipe 1, tipe 2A, dan tipe $2 \mathrm{~B}$ yang diturunkan secara autosomal dominant, dan tipe $2 \mathrm{~N}$, tipe 3 diturunkan secara autosomal resesif. Gejala klinis tiap tipe VWD berbeda, tergantung juga terhadap derajat keparahannya. Gejala klinis yang paling umum terjadi meliputi perdarahan gusi, hematuri, epistaksis, perdarahan saluran kemih, darah dalam fesese, mudah memar, menoragi. Pada pasien dengan tipe yang berat seperti tipe 3 yang tidak adanya fVW dapat terjadi hemartrosis, hematoma dan perdarahan jaringan dalam tubuh. 


\section{BIBLIOGRAFI}

Bakta, I. M. (2006). Hematologi klinik ringkas. Google Scholar

Bakta, I. M., SpPD-KHOM, F., Wibawa, I. D. N., SpPD-KGEH, F., Suega, K., Astika, I. N., \& SpPD-KGer, F. (n.d.). Pendidikan Kedokteran Berkelanjutan XXIII. Google Scholar

Chunaeni, S., Setiabudy, R. D., Gatot, D., \& Soedarmono, Y. S. M. (2019). To Improve Stability of Factor VIII Using Minipool Cryoprecipitate Lyophilized for Hemophilia a Treatment in Indonesia. Indonesian Journal of Biotechnology and Biodiversity, 3(2), 63-74. Google Scholar

Fithrah, B. A., Rasman, M., \& Saleh, S. C. (2019). Pengelolaan Central Diabetes Insipidus Pasca Cedera Kepala Berat. Jurnal Neuroanestesi Indonesia, 8(2), 99104. Google Scholar

Hasan, F., Anzar, J., \& Nazir, H. M. (2016). Sindroma Lesch Nyhan. Jurnal Kedokteran Dan Kesehatan: Publikasi Ilmiah Fakultas Kedokteran Universitas Sriwijaya, 3(2), 129-138. Google Scholar

Hasanan, F. (2018). Hubungan Kadar Homoglobin Dengan Daya Tahan Kardiovaskuler Pada Atlet Atletik Fik Universitas Negeri Makassar. Universitas Negeri Makassar. Google Scholar

Hoffrand, A. V, Pettit, J. E., \& Moss, P. A. H. (2005). Kapita Selekta Hematologi Edisi4. Jakarta: EGC, 104-114. Google Scholar

Mehta, A., \& Hoffbrand, V. (2008). At a glance hematologi. Jakarta: Erlangga. Google Scholar

Murni, M., \& Mayenti, F. (2019). Analisis Kejadian Hipertensi Berdasarkan Golongan Darah. Jurnal Endurance: Kajian Ilmiah Problema Kesehatan, 4(1), 8-16. Google Scholar

Price, S. A., \& Wilson, L. M. (2005). Patofisiologi konsep klinis dan proses-proses penyakit. Edisi Keenam. Jakarta: Buku Kedokteran EGC. Halaman, 163-224. Google Scholar

Proboningsih, A. (2020). Pengaruh Lama Penyimpanan Darah Sitrat Terhadap Pemeriksaan Plasma Prothrombin Time (PPT). Poltekkes Kemenkes Yogyakarta. Google Scholar

Putri, T. A. (2021). Pengaruh Jeda Waktu Pemisahan Serum terhadap Kadar Albumin. Poltekkes Kemenkes Yogyakarta. Google Scholar

Rofinda, Z. D. (2012). Kelainan hemostasis pada leukemia. Jurnal Kesehatan Andalas, 1(2). Google Scholar

Sudoyo, A. W. (2009). Buku ajar ilmu penyakit dalam jilid II. Google Scholar

Triandini, E., Jayanatha, S., Indrawan, A., Putra, G. W., \& Iswara, B. (2019). Metode Systematic Literature Review untuk Identifikasi Platform dan Metode Pengembangan Sistem Informasi di Indonesia. Indonesian Journal of Information Systems, 1(2), 63-77. Google Scholar

Wantania, J. J. E. (2016). Perdarahan uterus abnormal-menoragia pada masa remaja. 
Jurnal Biomedik: JBM, 8(3). Google Scholar

First publication right:

Jurnal Syntax Fusion: Jurnal Nasional Indonesia

This article is licensed under:

(@) $\odot \odot$ 